\title{
Analysis Learning Resources Based Local Potential of Pacitan Regency as Biology Learning in Senior High School
}

\author{
Ezif Rizqi Imtihana ${ }^{1^{*}}$, Djukri $^{2}$ \\ ${ }^{1}$ Biology Education, Postgraduate Program, Yogyakarta State University, Jl. Colombo No. 1, Karang Malang, \\ Yogyakarta, 55281, Indonesia \\ ${ }^{2}$ Biology Education, Faculty of Mathematics and Natural Science, Yogyakarta State University, Jl. Colombo No. 1, \\ Karang Malang, Yogyakarta, 55281, Indonesia \\ *Corresponding author. Email: ezifrizqi.2018@student.uny.ac.id
}

\begin{abstract}
This research is a preliminary study conducted with the purpose to know: 1) kinds of learning resources based local potential of Pacitan regency used as biology learning, 2) biological topic using local potential of Pacitan regency as learning resources, 3) difficulty learning resources based local potential used as biology learning. Data collection technique and instrument used questionnaire and interview with subject of research biology teacher in Senior High School of Pacitan regency. Data analysed descriptively using qualitative approach with the following steps 1) data collection, 2) data reduction, 3) data display, 4) drawing conclusion. The results showed that $75 \%$ schools use learning resources based local potential as biology learning with the kinds of local potential big percentage used coastal area, surrounding environment and cattle farm. The use of learning resources based local potential as biology learning most widely applied in biological topics biodiversity, ecosystem, animalia, environmental changes and bacteria. The difficulty learning resources based local potential used as biology learning influenced by factor: learning time, biology teacher, and environment condition.
\end{abstract}

Keywords: Biology, Learning resources, Local potential of Pacitan regency.

\section{INTRODUCTION}

National curriculum target of 2013 provides opportunity to develop variety of regional curriculum based local excellence, encourage quality teaching materials enrichment and varies to support the curriculum [1]. Learning concept based on Government Regulation Number 13 of 2014 about guidelines of learning implementation states that school are part of the community and it's can be learning resource in giving learning experience to students. Local potential as a part of the community is an exist resources in a region and it's can used biology learning resources. Learning resources based local potential expected stimulate students develop their skills because they can learn object study in real around of them. Direct interaction between students and learning resources is one of the 2013 curriculum learning modus that develop student's knowledge, thinking and skill. Interaction in the process of learning will contribute positively to learning process [2].

Essentially, studying biology is leaning about organism and their environment [3]. In biology, the use of learning resources should be adjusted with students' environment, experience and need. One way to get students closer with the biology object study is provide learning resources that can make students learning many things to everyday phenomena using local potential. Through real learning resources, the quality of learning resources used will better if compared using models or imitation. According to [4], integration local potential in learning materials can help students understand the concept correctly and contextually. Integration local potential in learning is needed in current situation where students as younger generation has decrease knowledge of culture and local potential in their region [5]. According to [6], the effort to overcome problem of degradation youth's respect to their regional potential is integrating local potential and local wisdom in learning. It's will make students know the values about local wisdom and potential so they will experience 
internalization of values that can make them personally characterized [5].

Research result about integration local potential in biology can improve learning outcome such as conceptual understanding and creative thinking [7], critical thinking [5], science literation [8] [9], science process skills [10], and conservation character [11]. It's known that integration local potential in biology learning makes positive contribution in improve students' ability of affective, cognitive and psychomotor. Therefore, in learning activities teacher not only emphasize cognitive aspect, but affective and psychomotor aspect must also be considered [6]. According to [12], learning with integrating local potential will increase student's respect to local potential and the value of local wisdom in their own environment, so it will indirectly effects of their learning outcomes (attitudes, habits and thinking abilities).

Pacitan regency is one of region located in East Java province, the southern part of the southwestern tip which has variety of local potential both of natural and cultural resource. Studies on the development about natural resources of Pacitan regency as biology learning resources have been carried out by several researchers such as in coastal area [13] [14] [15] and karst area [16]. Topography of Pacitan regency which mostly hill approximately $85 \%$, small mountains spread throughout Pacitan regency, steep ravines included seribu mountains longitudinal along south of Java island and the rest are lowlands [17] make Pacitan has abundant natural resources. Environmental balance of coastal areas, lands and forest areas become an ecological unit makes Pacitan regency have several potentials that can be used in educational field one of them as biology learning resources.

Availability of resource in Pacitan regency that have potential become biology learning resources encourages researcher to study how the use of biology learning resources based local potential in Senior High School of Pacitan regency. The purpose of this research was to knowing kind of learning resources based local potential used, biological topic using local potential as learning resources, and the difficulty in use it. To support the research purpose, the following research questions were asked:

1) What kinds of learning resources based local potential are used as biology learning?

2) What biological topics using learning resources based local potential?

What the difficulty use learning resources based local potential in Senior High School of Pacitan regency in biology learning?

\section{RESEARCH METHOD}

This research used a survey method with qualitative descriptive analysis.

\subsection{Location and Time}

This research conducted in Senior High School with the status of state school in Pacitan Regency. This research was a preliminary research using all Senior High School located in Pacitan regency. This research was conducted at October to December 2019.

\subsection{Subject of Research}

The sampling technique used was Purposive Sampling Technique with the subject is biology teacher in the $\mathrm{X}$ grade with the reason almost all biological topics in the $\mathrm{X}$ grade are concrete and its possible to use learning resources based local potential, so subject of this research were 8 biology teachers in all Senior High School of Pacitan regency.

\subsection{Data Collection Technique}

Data were collected using questionnaire and interview.

\subsubsection{Questionnaire}

It's used to determine the use of learning resources based local potential include kinds of local potential used and relevant biological topics using its as biology learning using questionnaire sheet in the form of checklist.

\subsubsection{Interview}

It's used to cross-check of main data based on questionnaire and get information about difficulty using learning resources based local potential as biology learning.

\subsection{Data Analysis Technique}

The research data obtained are primary data and analysed descriptively using qualitative approach with the following steps according [18].

\subsubsection{Data Collection}

Data collected according data collection technique.

\subsubsection{Data Reduction}

Select the required and organization data according research objectives about kinds and biological topics using learning resources based local potential, also difficulty learning resources based local potential used as biology learning.

\subsubsection{Data Display}

Presents data in tables and pie charts to combine the compiled information, and then will be analysed with the support of various literatures.

\subsubsection{Drawing Conclusion}

Concludes the outline of the research has been done to determine the use of learning resources based local potential in Senior High School of Pacitan regency. 


\section{RESULTS AND DISCUSSION}

Results based questionnaire show that not all Senior High School in Pacitan regency use learning resources based local potential as biology learning. Table 1 showed that learning resources based local potential of Pacitan regency has been advantage $75 \%$ as biology learning, means 6 of 8 schools have used learning resources based local potential as biology learning, while 2 other schools were not. The used learning resources based local potential as biology learning were by utilization in all of schools in Pacitan regency and there was not used its by design. It's means the use of local potential as biology learning resources not specifically designed by teachers but utilizing local potential that has been available. Application in learning, the use learning resources based local potential through student's assign outside school learning hours.

Table 1. List the use of learning resources based local potential as biology learning

\begin{tabular}{|c|c|c|c|}
\hline \multirow{2}{*}{ Schools identity } & \multicolumn{2}{|c|}{ The use of biology learning resources based local potential } \\
\cline { 2 - 4 } & By design & Bes utilization & \multirow{2}{*}{ No } \\
\cline { 2 - 4 } & - & $\checkmark$ & - \\
\hline A & - & $\checkmark$ & - \\
\hline B & - & $\checkmark$ & - \\
\hline C & - & $\checkmark$ & - \\
\hline D & - & $\checkmark$ & - \\
\hline E & - & - & $\checkmark$ \\
\hline G & - & - & $25 \%$ \\
\hline H & - & $75 \%$ & \\
\hline S & - & & - \\
\hline
\end{tabular}

The use of learning resources based local potential of Pacitan Regency not applied to all biological topics. It's because biology object study available in local potential doesn't cover all biological topics. It can be seen in table 2.

Table 2 showed that almost of concrete biological topics use learning resources based local potential. There were several local potentials used as biology learning resources, even the same local potential was used in the several biological topics. Local potential can be connected to local realities and local environment. Local reality is phenomenon in the environment including physical environment, social, local beliefs and insight while local environment is a phenomenon, event, problem or incident about environmental pollution and biodiversity [19]. Percentage in specifically about kinds of local potential and biological topics used seen in table 3 and figure 1.

Table 2. List kind of learning resources based local potential used in relevant biological topic

\begin{tabular}{|c|c|c|}
\hline Schools identity & Local potential used & Biological topic \\
\hline \multirow{2}{*}{ A } & Coastal area & Animalia \\
\cline { 2 - 3 } & Surrounding environment & Biodiversity, Animalia \\
\cline { 2 - 3 } B & Coastal area & Ecosystem, Biodiversity \\
\hline \multirow{2}{*}{ C } & Surrounding environment & Ecosystem \\
\cline { 2 - 3 } & Coastal area & Biodiversity, Ecosystem \\
\hline D & Surrounding environment & Biodiversity \\
\hline E & Coastal area & Animalia, Ecosystem, Biodiversity \\
\hline F & - & Bacteria, Animalia, The Environmental Changes \\
\hline G & Cattle farms & - \\
\hline H & - & \\
\hline
\end{tabular}


Table 3. Percentage kind of local potential used as biology learning resources

\begin{tabular}{|c|c|}
\hline Local potential used & Percentage \\
\hline Coastal area & $45 \%$ \\
\hline Surrounding environment & $44 \%$ \\
\hline Cattle farms & $11 \%$ \\
\hline
\end{tabular}

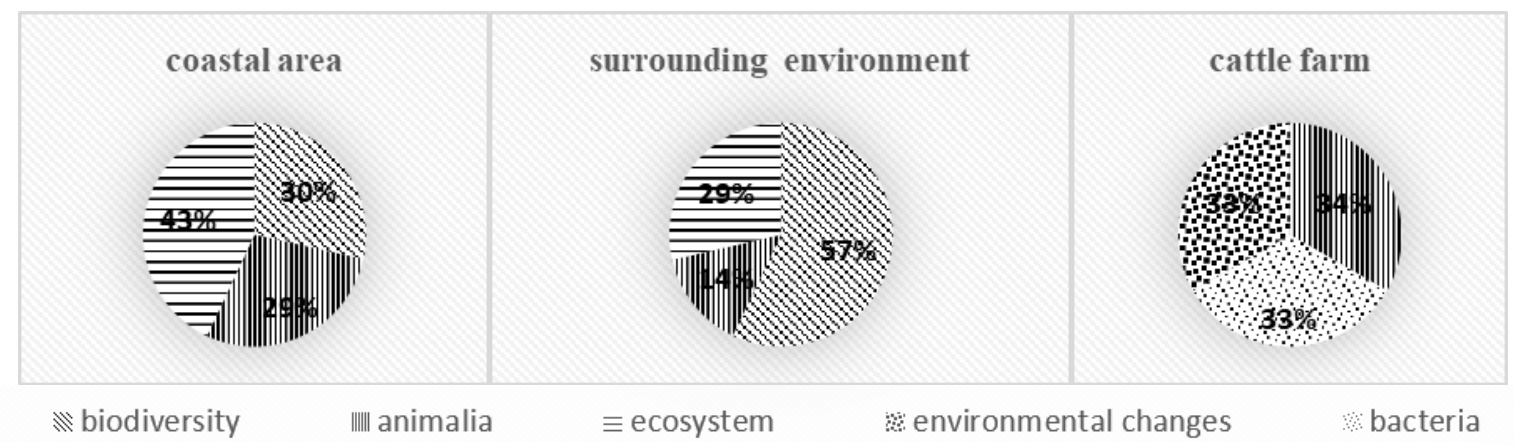

Figure 1 Percentage of biological topic used local potential as biology learning resources

The coastal area is the most local potential used as biology learning resources compared to other local potentials. It's because the geographical location of Pacitan regency in the south of Java island cause almost all over the southern region from the east to the western end of Pacitan regency were coastal area, so for schools in the southern Pacitan regency used coastal area as biology learning resources. Natural resources in coastal area of Pacitan regency consist of mangrove ecosystem and coral reef ecosystem [20]. Research by [20] state that one of the coastal areas in Pacitan regency have mangrove ecosystem and coral reef ecosystem. Natural learning resources such as coastal area can used as learning resources in supporting biology learning process because it's will give students opportunities to learn directly outside the classroom context [21]. Direct interaction with object study will make students possible to recognize, find out, analyze, prove and make conclusion about object study so, it's will help students to apply scientific principles in learning. Direct learning process will produce knowledge and skills knowing as instructional effects [22]. Besides the coastal area, surrounding environment around the school such as rice fields and greenhouse be alternative of learning resources based local potential used as biology learning. Also, cattle farm be other alternative biology learning resources for schools in the northern Pacitan regency because farm is the only local potential there.

Figure 1 showed that based 3 kinds of local potential used as biology learning resources, each used in different biological topics according its study. Biological topics of biodiversity, ecosystem and animalia used coastal area and surrounding environment as biology learning resources based local potential, while environmental changes, bacteria and animalia used cattle farm. Animalia become biological topics used all 3 kinds of local potential as biology learning resources. The percentage used coastal area as learning resources based local potentials greater that other local potentials on biological topic of animalia. It's because coastal area in Pacitan regency have many various specific marine animals such as Echinodermata, Mollusca and other aquatic invertebrates which has been studied and has potential as biology learning resources based local potential. Besides that, coastal area in Pacitan regency also have many various ecosystems such as mangrove ecosystem and coral reef ecosystem [20] that have potential as biology learning resources. Biological topic of ecosystem be easier to learn and understand if students can directly interaction with biological object study exist in nature [23] and it's the best way to studying ecology in outside or to the field [24]. Therefore, coastal area become learning resources in ecosystem biological topic used by most schools and has big percentage in used coastal area as biology learning resources. While local potential of surrounding environment is mostly used by schools on biological topic of biodiversity with the highest percentage among biological topics of animalia and ecosystem. Based interview with biology teacher who used learning resources based local potential as biology learning, surrounding environment is local potential easily accessible when used it as biology learning at school. Because Pacitan regency has variety of flora and fauna [17], so the object study can be found through the surrounding environment. For examples every school has greenhouse which plants diverse typical plant of Pacitan regency such as Clinacanthus nutans or Morinda citrifolia (pace) which considered as the origin of the name Pacitan. It's can used by teacher as biology learning resources when studying about biodiversity and 
effort to introduce local potential of Pacitan regency to students as young generation.

The difference of local potential used in each school influenced by location and the potential of region around school, so the biological topic used learning resources based local potential also adapts with local potential of region around school. The obstacles might happen in used local potential as biology learning resources is when the environment used for learning sometimes not always able show the things which desired. For examples when going to observation the diversity seagrass in coastal tidal area but evidently the waves in coastal area was high. Local potential can be connected to local realities and local environment. Local reality is phenomenon in the environment including physical environment, social, local beliefs and insight while local environment is a phenomenon, event, problem or incident about environmental pollution and biodiversity [1]. Based on the explanation, it's known that local potential used as biology learning resources in Senior High School in Pacitan regency was more directed to the local environment.

Although almost all schools used learning resources based local potential as biology learning, there are some difficulties felt by biology teacher integrating its. Almost all biology teachers gave the reason that the limited learning hours in schools didn't allow to use learning resources based local potential as biology learning. So, the tendency biology learning in school only uses available textbooks and teacher as main learning resources. Another reason about difficulties used learning resources based local potential as biology learning is the limitations of teacher in managing and packaging biology teaching materials from local potential into biology learning process on relevant biology topics. This is in line with research conducted by [25] states that some factors cause many schools not use local potential are the difficulty of time in making teaching materials and the determine of learning materials relevant to local potential. [26] state that in relation the use of natural resources in science learning, there are 3 factors influence the effort use learning resources based natural resources, 1) teacher's desire, 2) teacher's ability to see the natural resources based on learning, 3) teacher's ability to use natural resources around in learning. Therefore, biology teachers are required to have special abilities related to use of learning resources and develop their creativity so the local potential of Pacitan regency can integrated in biology learning as learning resources. It's can be effort to make students know the values of local potential and improve knowledge about local potential of Pacitan regency. Beside that it's can bring students closer to object study, so the biology learning becomes more meaningful and contextual based on the reality object of life accordance with the essence of biology learning.
Interview with biology teacher who used local potential as biology learning resources state that all of teacher used it in outside the context learning at school as assignment for students. It's one way that teacher do to get students closer to biology object study based local potential that was not found in classroom learning. Through integration local potential in biology learning as learning resources, students not only make opinions without supporting facts, but they were also encouraged to find answers from specific problems or phenomena observed. Based on this activity, it means that the learning applied a 'scientific approach'. Scientific approach is main foundation in the development of the 2013 curriculum and one of the learning strategies with expectation can improve students' competence. Therefore, in biology learning students not only use books and teachers as learning resources but also can explore their environment one of them through the integration of local potential. Biological object study that mastered in learning must able internalize biological value and integrate to everyday life so it will improve conservation character of students [11].

Biology learning should be able to create interaction between students and object study, not only by reading and memorizing or transferring knowledge from teacher to students. Biology learning ideally emphasizes interaction between students with their environment, so the result of learning who students get can be applied directly and becomes meaningful for students' personal. Biology plays a role in developing the potential of local resources and learn how to use and preserve its. Therefore, biology learning must include knowledge and attitudes of conservation about local potential so it's can motivate students to learn and develop their skills. Relevance of local potential to the real world encourages formation of practical application in contextual biology learning [27]. Local potential is learning resources based the environment, so its existence be a resource that can students used for learning [28]. Thus, biology learning based local potential provides opportunities for students to get knowledge and skills by involving the real world.

According to Regulation of Minister Education and Culture Number 103 of 2004 state that every biology teacher is expected to initiate contextual biology learning. Biology learning as a part of education has great potential in used environment as learning resources. By used local potential which internalized in biology learning will have an effect for teacher to develop biology as tool in presenting biological topic appropriate with everyday life [29]. Activities which leads used local potential can be focus of school programs in supporting students' need. Therefore, starting from local problems around of students they guided learn to identify environmental problems around them and can provide solution for the possible impact. 


\section{CONCLUSION}

Based on this study, $75 \%$ Senior High Schools in Pacitan regency use learning resources based local potential as biology learning. It's 3 kinds of learning resources based local potential are used as biology learning: coastal area, surrounding environment and cattle farm. Biological topics using learning resources based local potential: animalia, biodiversity, ecosystem, environmental changes, and bacteria. The difficulty use learning resources based local potential in Senior High School of Pacitan regency in biology learning influenced by learning time, biology teacher, and environment condition. This result can be used as basis for further study in integrating local potential of Pacitan regency as learning resources in others relevant biological topic.

\section{AUTHORS' CONTRIBUTIONS}

1 and 2 contributed to the research design. 1 contributed to the implementation of research, result analysis and writing manuscript. 2 contributed providing critical feedback and helped result analysis and cpcorrection of manuscript.

\section{ACKNOWLEDGMENTS}

I would like to express my gratitude to my advisor and all those who participated in the writing of this paper, also to Education Authorities of Pacitan regency which has given permission to conduct this study in Senior High School of Pacitan regency.

\section{REFERENCES}

[1] U.N.A.D. Jayanti, H. Susilo, E. Suarsini, Analisis kebutuhan bentuk sumber belajar dan media pembelajaran biologi berbasis potensi lokal untuk kelas X SMA di Provinsi Lampung, in: Prosiding Seminar Pendidikan IPA Pascasarjana UM, vol. 2, Pascasarjana UM, Malang, 2017, pp. 591-599.

[2] Y. Pantiwati, Pemanfaatan lingkungan sekolah sebagai sumber belajar dalam lesson study untuk meningkatkan metakognitif, in: M. F. Saifuddin (eds) Jurnal Bioedukatika, vol 3(1), Universitas Ahmad Dahlan, Yogyakarta, 2015, pp. 27-32. http://dx.doi.org/10.26555/bioedukatika.v3i1.4144

[3] R.P. Kurnia, I.G.P. Suryadharma, Perangkat pembelajaran biologi kegiatan ecotourism untuk mengasah keterampilan proses sains dan sikap peduli lingkungan, in: Z.K. Prasetyo (eds) Jurnal Inovasi Pendidikan IPA, vol 2(2), Universitas Negeri Yogyakarta, Yogyakarta, 2016, pp. 230240. https://doi.org/10.21831/jipi.v2i2.12252

[4] T. Laurens, C. Laamena, Matitaputty, Development a set of instructional learning based realistic mathematics education and local wisdom, in: Proceedings of International Seminar Innovation in Mathematics and Mathematics Education, vol 1, Universitas Negeri Yogyakarta, Yogyakarta, 2014, pp 571-576.

[5] I. Wilujeng, Z.K. Prasetyo, I.G.P. Suryadharma, Science learning based on local potential: Overview of the nature of science $(\mathrm{NoS})$ achieved, in: AIP Conference Proceedings, 1868 080005, AIP Publishing, Indonesia, 2017, pp 1-7. https://doi.org/10.1063/1.4995189

[6] A.P. Kurniawati, Z.K. Prasetyo, I. Wilujeng, I.G.P. Suryadharma, The effectiveness of science domainbased science learning integrated with local potency, in: AIP Conference Proceedings, 1868 080001, AIP Publishing, Indonesia, 2017, pp 1-8. https://doi.org/10.1063/1.4995185

[7] K.T. Tamimiya, I.G.P. Suryadharma, Potensi lokal gunung Ijen untuk pemahaman konsep dan berpikir kreatif pengurangan resiko bencana, in: Z.K. Prasetyo (eds) Jurnal Inovasi Pendidikan IPA, vol 5(1), Universitas Negeri Yogyakarta, Yogyakarta, 2019, pp 117-128. https://doi.org/ 10.21831 /jipi.v5i1.25702

[8] A. Putri, Suciati, M. Ramli, Pengaruh model problem based learning berbasis potensi lokal pada pembelajaran biologi terhadap kemampuan literasi sains siswa kelas X SMA Negeri 1 Cepogo, in: BIO-PEGADOGI Jurnal Pembelajaran Biologi, vol. 3(2), Universitas Sebelas Maret, Surakarta, 2014, pp 81-94.

[9] B. Setiawan, D.K. Innatesari, W.B. Sabtiawan, S. Sudarmin, The development of local wisdom-based natural science module to improve science literation of students, in: Dr. Parmin (eds) Jurnal Pendidikan IPA Indonesia, vol 6(1), Universitas Negeri Semarang, Semarang, 2017, pp 185-194. https://doi.org/10.15294/jpii.v6i1.9595

[10] R.R.B. Rahardini, I.G.P. Suryadharma, I. Wilujeng, The effect of science learning integrated with local potential to improve science process skills, in: AIP Conference Proceedings, 1868, 080008, AIP Publishing, Indonesia, 2017, pp 1-6. https://doi.org/10.1063/1.4995192

[11] M. Khusniati, Parmin, Sudarmin, Local wisdombased science learning model through reconstruction of indigenous science to improve student's conservationist character, in: S. Çepni, Ü. Ormanc1, İ. Deveci, B. B. ÜLGER (eds) Journal of Turkish Science Education, vol 14(3), Uludağ Üniversitesi Eğitim Fakültesi, Turkey, 2017, pp 1623.

[12] I. Wilujeng, I.G.P. Suryadharma, The effectiveness of integrating local potential on science process skills and conceptual understanding, in: B. AlKurdi (eds) Proceedings of the International Conference on Learning Innovation, vol 164, 
Atlantis Press, Paris, 2017, pp 17-21. https://dx.doi.org/10.2991/icli-17.2018.4

[13] F.K. Muzaki, E. Setiawan, G.F.A. Insany, N.K. Dewi, I.B. Subagio, Community structure of Echinoderms in seagrass beds of Pacitan beaches, East Java, Indonesia, in: Sutarno (eds) Biodiversitas Journal of Biological Diversity, vol 20(7), Universitas Sebelas Maret, Surakarta, 2019, pp 1787-1793. https://doi.org/10.13057/ biodiv /d200701

[14] I. B. Setyawan, W. Prihanta, E. Purwanti, Identifikasi keanekaragaman dan pola penyebaran makroalga di daerah pasang surut pantai pidakan kabupaten Pacitan sebagai sumber belajar biologi, in: A.M. Hudha (eds) Jurnal Pendidikan Biologi Indonesia, vol 1(1), Universitas Muhammadiyah Malang, Malang, 2015, pp 78-88. https://doi.org/10.22219/jpbi.v1i1.2305

[15] N.K. Dewi, S.A. Wibowo, Status padang lamun pantai-pantai wisata di Pacitan, in: I.R. Aziz (eds) BIOGENESIS Jurnal Ilmiah Biologi, vol 3(1), Universitas Islam Negeri Alauddin Makassar, Makassar, 2015, pp 53-59. https://doi.org/10.24252 /bio.v3i1.567

[16] I.D. Kurniawan, C. Rahmadi, R.E. Caraka, T.E. Ardi, Cave in Gunugsewu karst area, Pacitan, East Java, Indonesia, in: Sutarno (eds) Biodiversitas Journal of Biological Diversity, vol 19(3), Universitas Sebelas Maret, Surakarta, 2018, pp 857-866. https://doi.org/10.13057/biodiv/d190314

[17] Badan Pusat Statistik Kabupaten Pacitan, Letak geografis kabupaten Pacitan, in: Website Badan Pusat Statistik Kabupaten Pacitan, Pacitan, 2014. https://pacitankab.bps.go.id/

[18] B.M. Miles, H. Michael, Analisis data kualitatif buku sumber tentang metode-metode baru, UIP Press, 1992.

[19] R. Marlina, Pemanfaatan lingkungan lokal dalam kegiatan laboratorium berbasis inkuiri terhadap sikap ilmiah mahasiswa calon guru biologi, in: L. Lukmanulhakim (eds) Jurnal Visi Ilmu Pendidikan, vol 10(1), Universitas Tanjungpura, Pontianak, 2013, pp 1052-1060. http://dx.doi.org/10.26418/ jvip.v10i1.2064

[20] Sukandar, C.S.U. Dewi, R.S.Q. Haq, C.J. Harsindhi, Fatmawati, Ekowisata pesisir dan laut Jawa Timur (Pacitan, Trenggalek dan Tulungagung), Bidang Kelautan, Pesisir Dan
Pengawasan Dinas kelautan dan perikanan Prov. Jawa Timur, 2017, pp 53-84.

[21] R. Utina, A.S. Katili, E. Nusantari, Y. Tamu, Coastal ecosystem capacity as a study material in biology learning in the coastal areas, in: A.R.M. Al-Tawaha Australian Journal of Basic and Applied Sciences, vol 11(13), AENSI Publisher, Amman, Jordan, 2017, pp 122-127.

[22] T. Rachmawati, Daryanto, Teori belajar dan proses pembelajaran yang mendidik, Gava Media, Yogyakarta, 2015.

[23] A. Puspitasari, R.C. Handziko, Pengembangan LKPD mobile learning guided discovery untuk meningkatkan penguasaan kompetensi dasar ekosistem kurikulum 2013, in: Z.K. Prasetyo (eds) Jurnal Inovasi Pendidikan IPA, vol 4(1), Universitas Negeri Yogyakarta, Yogyakarta, 2018, pp 83-97. https://doi.org/10.21831/jipi.v4i1.17003

[24] E.P. Odum, Dasar-dasar ekologi, terjemahan dari fundamentals of ecology, UGM Press, 1998.

[25] T. Prihandono, S. Wahyuni, Z.S. Pamungkas, Development of module based on local potential integrated SETS in junior high school, in: K. TATLILIOĞLU (eds) The International Journal of Science Sciences and Humanities, vol 4(9), Valley International, India, 2017, pp 3939-3944. https://doi.org/10.18535/ijsshi/v4i9.07

[26] Karwono, M. Heni, Belajar dan pembelajaran serta pemanfaatan sumber belajar, Rajawali pers, 2017.

[27] A.P. Kahar, R. Fadhilah, Pengembangan perangkat pembelajaran biologi SMA berbasis potensi lokal, literasi lingkungan dan sikap konservasi, in: B. Irawan (eds) PEDAGOGI HAYATI Jurnal Ilmiah Pendidikan Biologi, vol 2(2), Universitas Maritim Raja Ali Senggarang, Riau, 2018, pp 16-24. https://doi.org/10.31629/ph.v2i2.832

[28] S. Sukardi, Desain model prakarya dan kewirausahaan berbasis ekonomi kreatif berdimensi industri keunggulan lokal, in: B. Nurgiyantoro (eds) Cakrawala Pendidikan Jurnal Ilmiah Pendidikan, vol 35(1), Universitas Negeri Yogyakarta, Yogyakarta, 2016, pp 114-124. https://doi.org/10.21831/cp.v1i1.8381

[29] R.P. Situmorang, Analisis potensi lokal untuk mengembangkan bahan ajar biologi di SMA Negeri 2 Wonosari, in: Jurnal Pendidikan Sains, vol 4(1), Universitas Muhammadiyah Semarang, Semarang, 2016, pp 51-57. https://doi.org/ $\underline{10.26714 / \mathrm{jps} .4 .1 .2016 .51-57}$ 